\title{
The Application of the Innovative Approaches in Communication and the Educational Processes
}

\author{
Marica Mazurek \\ Žilina University
}

The influence and impact of innovations in a society is not identical and some innovations penetrate a society more radically: the influence of others may only be incremental. For example, in tourism a radical impact on marketing communication processes has come with the development of ICT technologies. Johanesson et al. (2001), Dosi (1982) associated revolutionary change with radical innovation, and the process of continual change and implementation of novelty considered as incremental innovation. Despite a more radical character, incremental innovations stem from market needs and are strategically easier to proceed with because a process of the implementation can be planned. The article will deal with the concepts of the innovative social technologies and their application in the teaching process. It means the study of successful cases, where the clusters of intelligence based on the diffusion of knowledge and the cooperation and mutual communication and partnership of the educational institutions with the innovative businesses.

Keywords: innovative approach to education, Triple-Helix model, partnership, place branding, smart cities and territories

\section{INTRODUCTION}

One of the managerial tools of communication in specific places is different e-technologies as well as artificial intelligence, which could be used in the consumer approach process as well as the supply side approach. The concept of ambient intelligence means a creation of the clusters of intelligence of high tech environments (artificial intelligence, business modeling and brand models application). This concept corresponds to the new age based on the "mobilization of ideas, knowledge and expectations" and technologies, which can be used also in branding, as for instance experience economy concepts. Moutinho, Rita and Curry (1996) mentioned that artificial intelligence (AI) has scarcely touched today's managers; it will begin to have dramatic and widespread impacts on their activities over the next few years. Knowledge is an important competitive tool for innovation, in the new, post- capitalist society that is based on a knowledge economy. Drucker (1993, p. 38) stated that "knowledge is the only meaningful resource today"; however, this might be a little misleading, because it is not only about the possession of knowledge, but also the diffusion and use the knowledge for the company, or a region, country. Diffusion and transformation of knowledge is crucial. For this reason is sometimes important to focus not only on the supply side concepts, but also demand and consumers and their desire and especially implement in the new communication strategies the technologies based on the innovative principles. 
The educational institution in a city might be a good example of the innovative and smart decisions leading to the growth of competitiveness of cities. Hjalager (2002) supported the idea of the importance of the institutional innovations and Ward (1998) mentioned that universities and research institutes are key entities to promote smart technologies and decisions in a city (Triple Helix concept). In this concept is crucial the enforcement of smart technologies and new visions. The interactive model of co-operation, embedded in a concept of the entrepreneurship university, has been used instead of the former linear model.

A territory represents a place which is significant for the economic and social development. The application of modern approaches to strategic innovation management and marketing of a specific territory (in our case a city) and especially the implementation of modern and innovative approaches to governance (co-creation and partnerships, especially among the educational institutions of cities, public and private sector entities) has been one of major factors of success of specific countries and especially cities in the world, which were able to apply the innovative management and marketing tools. These good examples could be used in the other cities in order to benchmark their experiences of practices for their success. One of good examples could be the Triple Helix model or concept, which has been known already for a period of time before, but the application of this model could be found as very successful in the city of Waterloo, Canada and could be a good evidence of the importance of education and the innovation synergy in smart cities.

\section{BACKGROUND}

The creation of competitive territories requires the implementation of the factors of competitiveness and the economic growth and development (for instance Reinisto, 2003 mentioned such factors as the economic stability, costs, productivity, local support of services and networks), but important are also so called "soft factors", which are becoming crucial for cities and their competitiveness (quality of life, culture, management, flexibility and dynamics, partnerships, co-creation of value with the customers).

Merging of the factors of competitiveness with the social factors of the environment is a good example of a holistic approach to the city development. The so called "soft factors" are based on the creation of positive image, ethical principles, credibility and tolerance, especially a reputation of a territory. Especially, partnerships in territories (cities) are one of the most important trends in marketing of territories. Kotler (2002b) stated that local partnerships with companies and the representatives of public sector are critical factors of success.

One of good examples of successful approaches to marketing of cities is place branding, which has been also supported by Reinisto and Moilanen, Go and Govers, Hankinson, etc. This concept is embedded in the principle of brand equity forming, which is based on the creation of a positive image and loyalty of consumers (users of a territory). Brand equity principle is based on the creation of value with a customer and as Go and Govers (2009) stated "place branding is mobilizing the creation of partnerships and networks between the private and public sector in order to create the offer in territories". For this reason, partnerships are crucial for the improvement of competitiveness.

Ward (1998) mentioned that the universities and research institutes are the key elements and are often important partners of the public and private partnerships. Creation of the co-operative platform between a city and the academic environment (Triple Helix approach) is crucial for the establishment of potential for the innovation and the economic growth; moreover, it is necessary for the knowledge economy growth in cities and their successful development. Similar ideas were later introduced by the authors as Cai (2013).

The authors as Etzkowitz and Leydesdorff (2000), Deakin, M., Leydesdorff. (2013). studied this topic from the point of view of the successful territories (cities) and their research was focused on the creation of strategic alliances of the academic institutions in cities with the local public sector representatives and the entrepreneurs. The authors Etzkowitz and Leydesdorff (2000) claimed that this type of partnership can create a new innovation milieu, which leads to the regeneration of the whole system in a territory (city). Exactly the same opinion and trends offers the "New Theory of Growth" (Romer and Arthur) and these ideas were also mentioned in the concepts of the "New Economic Geography" (Krugman, 1995, Porter, 1998). 
These theories underline the importance of knowledge and knowledge capital, technologies and stress a necessity of governmental support in order to improve the behavioral and technological parameters of territories (cities), processes and focus on the growth of educational level of territories (cities), information flow, and creation of networks (partnerships). Crucial is the idea of cluster and partnerships forming, especially among the educational environment and the public and private entities in a city as well as the importance of knowledge capital, technologies and the improvement of behavioral and technological parameters of cities. The representatives of these ideas were for instance Barro, X. Sala-i-Martin (1995). Hjalager (2002) mentioned that this might be an example of the institutional innovation. The following example (Morschett et al., 2009) is the system of innovation (knowledge infrastructure).

\section{FIGURE 1 \\ EDUCATIONAL INFRASTRUCTURE}

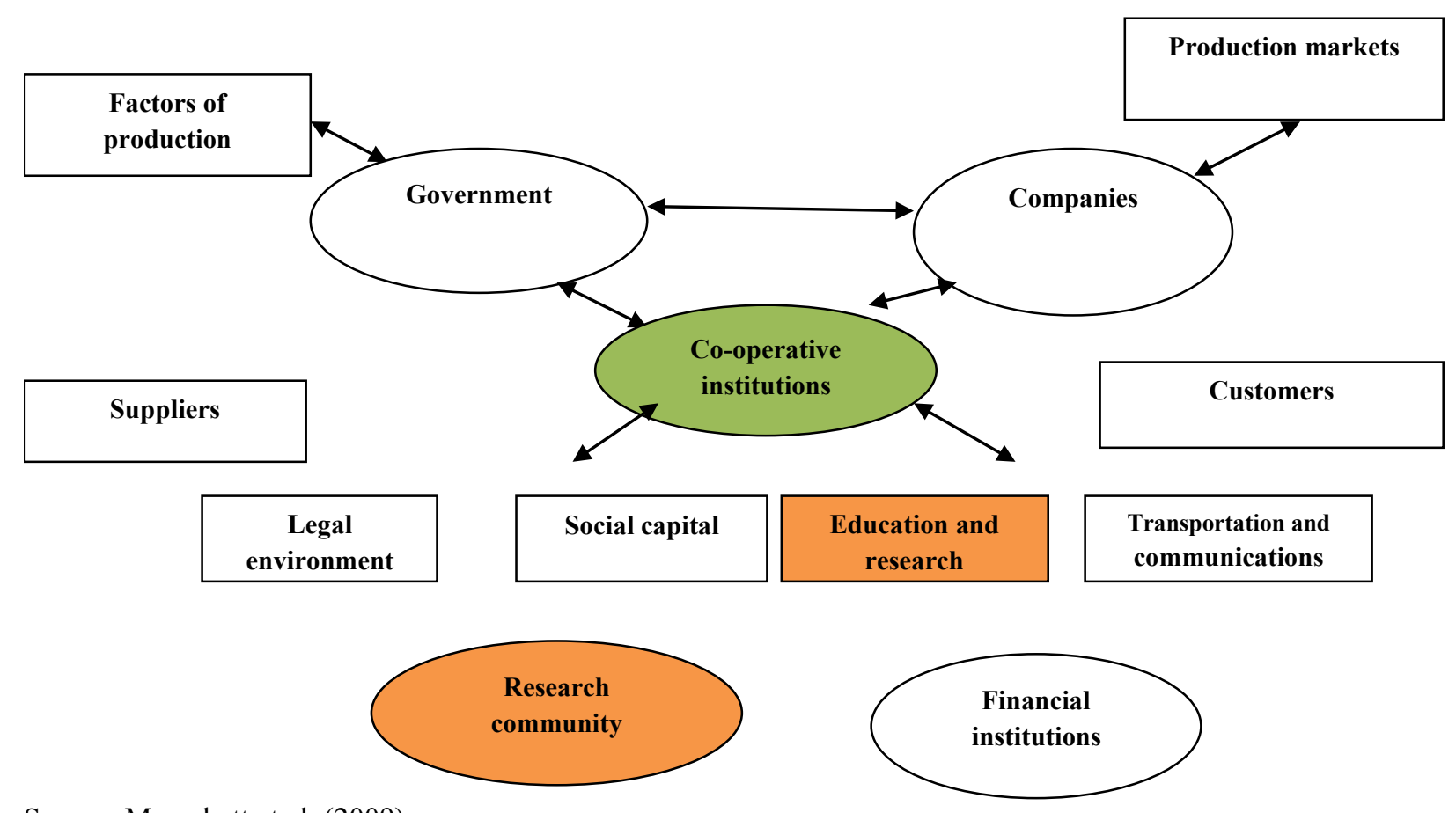

Source: Morschett et al. (2009).

The main concept is the "entrepreneurship focused university", which enforces the interactive model of innovation instead of the linear model. The interactive model contains the feedback components and the following figures explains the concept and the role of marketing and educational product as well as the ideas of innovation incorporated in the model. 


\section{FIGURE 2}

\section{THE INTERACTIVE MODEL OF INNOVATION (AMENDED UPON THE RELATIONSHIP}

TO THE EDUCATIONAL PRODUCT)

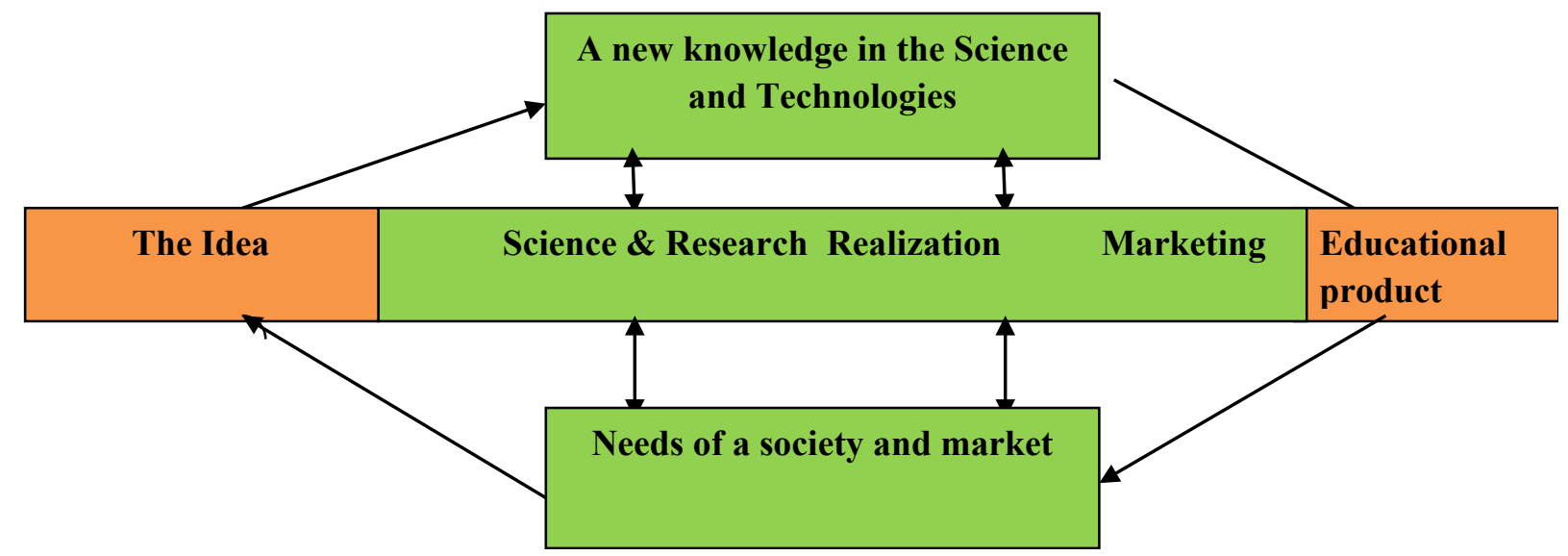

Source: amended and based on Rothwell and Zegveld (1985).

In accordance to the newest trends of development and competitiveness should be mentioned some new concepts and ideas, which have been developed for instance at the 3rd Global Summit on city tourism "New paradigms in City Tourism Development" in Barcelona, where Buhalis (2014) defined a smart territory as a territory, which is typical for its innovative approach and development and invests into the human and social capital. Crucial are the participatory governance, partnerships, and technologies, human and social capital as has been commented in the following figure by Buhalis (2014). This concept concerns not only tourism development, but could be generalized for the other activities in a city.

FIGURE 3

\section{SMART CITY}

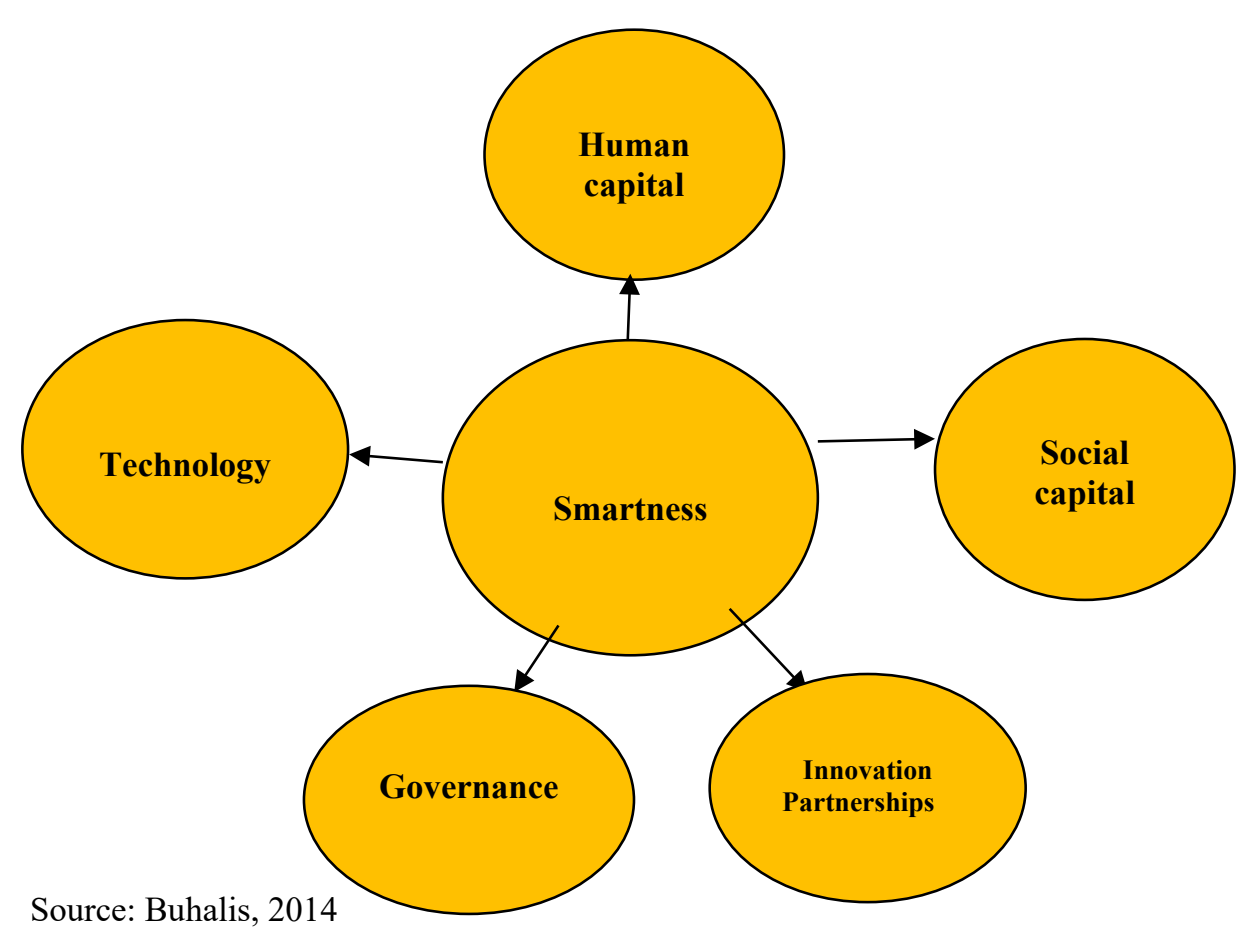


The authors as Anthopouls et. al (2011), Carvalho et al. (2015), Hollands (2015), Kitchin (2015), Nam et. al (2011), Shelton (2015), Suzuki et al. (2013), Suzuki (2017) supported the idea of smart cities creation and development (Figure 4).

FIGURE 4

MODEL OF A SMART CITY

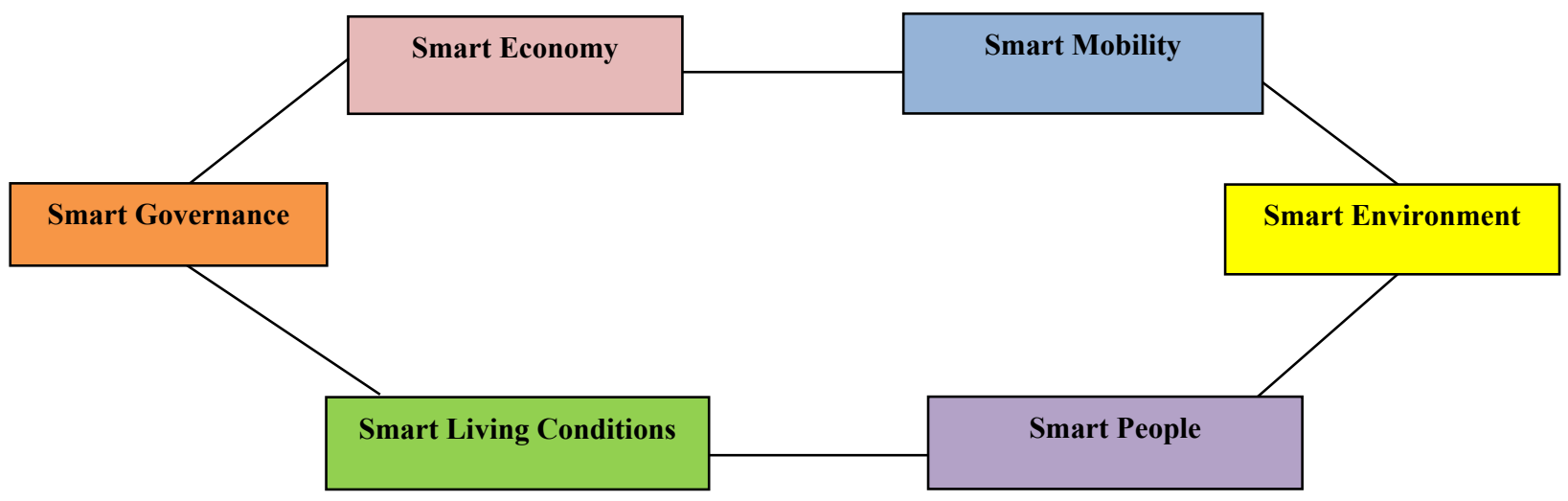

Source: www.smart-cities.eu, 2016.

Merging of the modern technological environment with the ethical social environment and the economic environment is the precondition of the innovative development of cities. The following 6-stars model contains the requirements for a successful development of cities.

\section{FIGURE 5}

6 STARS MODEL AMENDED FOR THE TERRITORIAL PURPOSES (CONCEPT OF CCM)

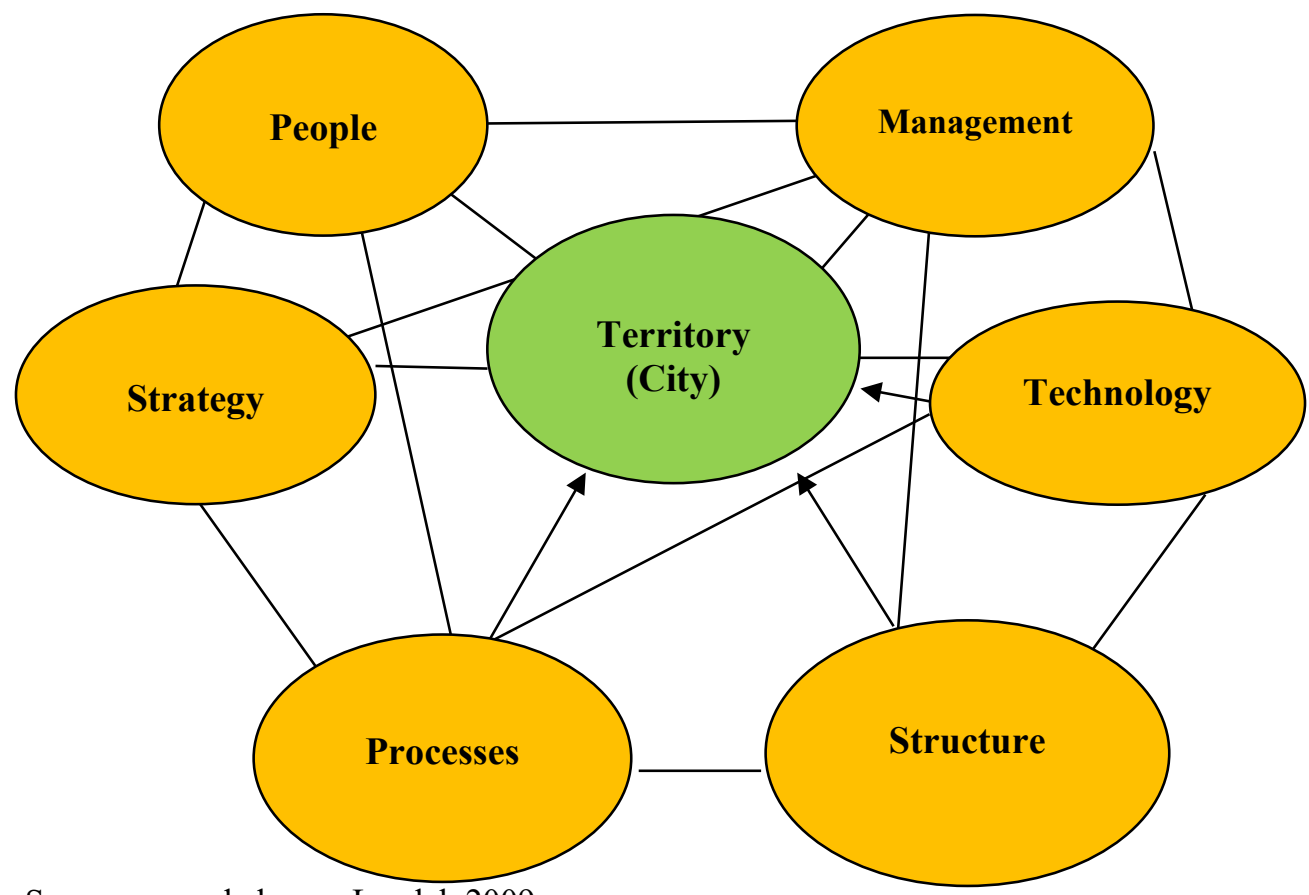

Source: amended upon Lendel, 2009. 
The application of these approaches and models are visible in many successful cities in the world and especially the application of Triple Helix approach and smart city concepts are present in cities, which are competitive, popular among entrepreneurs, students and citizens. The success stories of these cities and additionally also territories, countries might be a good example for the other cities, which are looking for a better position and managerial progress. One of such countries is also Canada and the Technological Triangle Kitchener-Waterloo-Guelph. In our study, we were mostly focused on the city of Waterloo, where is situated the most innovative university of Canada, the University of Waterloo.

\section{METHODOLOGY}

During a research both primary and secondary research approaches were applied. The sources of secondary research were internet publications, projects dealing with the studied topic, especially dealing with the partnerships and smart destinations content, studied materials about the municipality Waterloo. Primary sources of the research were especially discussions with the representatives of the public sector in the city of Waterloo and the academics from the University of Waterloo during a postgraduate study stay at the University Waterloo from 2006-2010. In this period of research have been interviewed the representatives of the academic environment, e.g. professors, administrators of the University of Waterloo during the formal or informal discussions and interviews. Some of the interviewed academics were members of public -private partnerships and had an expertise as the governmental representatives in specific commissions and boards. The method of case study has been applied and the qualitative research enabled to obtain results, which were able to create a picture of the case of Waterloo and indicate the reasons of its success story. This research was conducted in several stages during the stated period of time, especially during the personal stay in Canada; however, some later period should also be mentioned, especially the years 2011 till 2016, when the additional materials were collected during the additional visit and research in Canada and personal and digital contact, correspondence and research (e-mails, skype, Facebook, etc.).

Concerning the research method of case study Stake (2005), Cresswell (2009), Yin (2009, 2004, 2003) and the others recommend this method as a suitable method for the application of the inductive approach, which allows applying the existing theories. Cresswell (2007) stressed the importance of this method especially if a researcher wanted to apply several sources of results during a longer period of time in order to achieve a richness of data and problem understanding. Method of case study has been supported by Smith and Xiao (2006), Cresswell (2002) and Patton (2002). The method of structured and unstructured discussion was used for the improvement of the empirical research, which is also our research and the findings are based on the primary and mostly secondary sources. Empirical research is a first stage of research, which might create a thorough picture of the studies case and especially is also based on the personal experience, which has been incorporated into the findings. The originality of research and findings is that they are not only based on the existing sources, but a researcher had to experience the innovative environment during a longer period personally. Discussions were conducted or online, by e-mails or personally and some questions were resent again for obtaining a clearer picture. Several other methods have been used, for instance the method of analysis of results, comparative analysis, synthesis, analogy, generalization, etc.

\section{FINDINGS}

Waterloo region with over half a million citizens is familiar for its competitiveness in Canada, and the city of Waterloo with its approximately 113 thousands inhabitants bears the same designation as the whole region. City of Waterloo is familiar to be as a part of so called Technological and Knowledge Triangle, which fame is based on the high-tech technologies in a co-operation with one of the most innovative universities not only in Ontario and Canada, but all over the world. The Waterloo University belongs to the best universities in the world and in the ranking of McLeans occupies the first place in innovations among the Canadian university environment. 
The university is predominantly science oriented and the newest study programs are focused on nanotechnologies. The study programs are closely connected with the practical field and entrepreneurship platform, for instance the Science and Technological Park Research in Motion (RIM), which was familiar for the production of BlackBerry cell phones. In Waterloo exists also Wilfred Laurier University with a strong Business program. University Waterloo has its campus also in Abbu Dhabi in Saudi Arabia, but based on the latest research, the University of Waterloo cannot fill the number of students in Dubai after three years of existence. A partnerships with the United Arab Emirates Higher Colleges of Technology still does not guarantee a full number of planned students (about 500), and for this reason the University of Waterloo had to shutter its branch campus in Dubai.

In Waterloo, besides the international high-tech company RIM are several important high-tech companies as for example Desire2Learn a OpenText, McAfee, Agfa, Sybase, Google, Electronic Arts, Dalsa and Sandvine, Kik Interactive, Miovision Technologies, Thalmic Labs, etc. In Waterloo is also a seat of the Perimeter Institute for Theoretical Physics, which is focused on the world research in technologies (nanotechnologies) and physics. Another partner of the educational institutions and the city is The Centre for International Governance Innovation and the Institute for Quantum Computing.

City of Waterloo is a leader in innovations in Canada with the highest index of patents, entrepreneurship incubators and start-ups. Results of a primary research revealed that the ethics and positive image, good governance are important for a success of Waterloo. The respondents mentioned especially the importance of the investment and entrepreneurship opportunities, culture, quality of educational facilities, health care, social services, employment opportunities, etc. Waterloo ranks as the $25^{\text {th }}$ city in the world in the creation of ecosystems and start-ups. For this position, the city had to be one of the leaders in partnerships, technical talents and especially to be a place of the existing academic environment with two excellent universities.

Municipality of Waterloo is strongly involved in the co-operation with the universities in the creation of start-up businesses, especially the University of Waterloo. There exists the Business Educational Partnerships, which allows the students to be part of practical education in local businesses. Crucial is also a governmental support of mutual financial help from public sources and additional support from private sources for the scientific and technological purposes. One example is the network Communitech and Accelerator Centre as a subject of mutual co-operation between the universities and the professional entrepreneurship entities. University of Waterloo creates the partnerships with the region of Waterloo, city of Waterloo, cities of Kitchener, Cambridge, Stratford, Dumfries, Wellesley, Wilmont and Woolwich.

The University of Waterloo is tightly joined in a co-operation with the Chamber of Commerce and the Deputy for Entrepreneurship (CAO). Important partner for the University of Waterloo is Communitech, which is also a sponsor of several events in the city, for instance Waterloo Innovation Summit, Techtoberfest, TechLeadership Conference a Startup Weekend. One the important example of co-operation between the University Waterloo and partners is the pilot program ASCEnt (Accelerating Social Cause Entrepreneurs). Close co-operation of the academic institutions and city of Waterloo with a twin city of Kitchener have doubled the investments into both cities, especially in the area of the use of 3D technologies in health care, entertainment business, architecture, internet media, digital publications and music. Government of Ontario also supports financially the creation of start-ups in the province in so called the Entrepreneurs Residence program and MaRS Market Intelligence program. For example in 2014 the investment of Canada into start-ups was more than 2.3 billion CAD.

University of Waterloo co-operates tightly with the American Silicon Valley and the co-operation is based on the exchange of students, practices, and experts. City of Waterloo established special centers in the city, which contain about 6000 companies with approximately 250 thousand of employees in IT sector of Ontario. One example is Ontario Technology Corridor. IT technologies sector represents in this city an entity, which is able to create $20 \%$ of GDP of Canada. Directly at the University of Waterloo is placed the Accelerator Centre, which supports the entrepreneurship of high-tech technological companies.

One of the last examples of the partnership of city of Waterloo, in order to become a leading smart city in the world and create the intelligent community, is the creation of the strategic partnership with the company Intuitive Business Intelligence Today and the company OpenText. In 2007, city of Waterloo has been designated in New York as a city, which belongs to the world intelligent communities (ICF). Important 
factor for the city is a close co-operation with both universities and the improvement of governance in the city. For instance it was a creation of so called "information governance" (Enterprise Information Management), which is focused on the cloud management and techniques, integration of data, regulation, etc. Tight co-operation exists among the partners of the city and the university with several think tanks as for instance the Perimeter Institute, Center for International Governance, but also the institutions of the creative business. As an example of mutual successful co-operation among the University of Waterloo and the other partners in the city could be mentioned two case studies - Communitech partnership and Velocity.

Case study Communitech is a partnership of 450 partners mostly focused on innovations, leadership, networks, and promotion. Communitech is a partnership, which aim is to „support technological companies in the whole region, in the cities of Waterloo and Kitchener and the creation and support of the whole territory as the technological cluster" and the creation of the digital network Canadian Digital Media Network (CDMN). Another good example of partnership is MIN (Manufacturing Innovation Network) as a partnership of local producers, academic institutions, municipal government, and associations involved in marketing, network creation and innovations. The goal of MIN is to centralize e-market and the innovation activities as well as the brand awareness creation.

Case study Velocity is one of the examples of the co-operation of the University of Waterloo with the local entrepreneurship environment. Similar program at the Wilfred Laurier University is called Launchpad. Since 2008 Velocity enabled to start entrepreneurship of 160 start-up companies, collected about 250 million CAD, and created about 800 working positions. The company Velocity usually does not reveal its annual budget, but it is well known that for its activities collected in the past approximately 2 million CAD as a personal gift from the company Kik and its founder Teda Livingston as well as the financial support from the Ontario government and Canadian government.

\section{CONCLUSION}

Functioning of partnerships, excellent reputation and image of a place are important for a city, especially partnerships with the academic institutions and research institutes. Knowledge capital and smart technologies in cities as well as the partnerships among the educational institutions and the private and public sector representatives are based on several opinions of different authors as Etzkowitz and Leydesdorff (2000) and are one of the important tools of success in the period of smart technologies growth. The innovations, which are institutionally based (as stated by Hjalager, 2002) stress the value of research institutes, smart technologies and smart decisions in cities, which is the confirmation of the idea that Triple Helix concept is really important concept for the cities, which want to succeed.

The application of modern approaches to strategic innovation management and marketing of a specific territory (in our case a city) and the implementation of modern and innovative approaches to governance (co-creation and partnerships, especially among the educational institutions of cities, public and private sector entities) has been one of major factors of success of specific countries and especially cities in the world, which were able to apply the innovative management and marketing tools. It has been studied in several conceptual materials before starting of this research.

Education, knowledge, reputation, image, partnerships and co-creation are nowadays trends of success. For this reason it is not a surprise that several private entrepreneurial businesses supported research and education at the University of Waterloo and contributed almost $10 \%$ of their profits for the educational and research purposes. The investment and partnerships with the universities, which are not only innovative, but also offer the educational product at a high qualitative level, is one of the preconditions of the effective leadership and success. Waterloo is one good example of it and many of cities and universities should learn from it. It should be a rule in such countries, where the education is not a priority. 


\section{REFERENCES}

Buhalis, D. (2014, December 9-10). Contribution on smart tourism to the UNWTO 3rd Global Summit on city tourism. New paradigms in City Tourism Development. Barcelona.

Buhalis, D. (2014, December 9-10). Technologies for tourism Destinations. 3rd Global Summit on City Tourism: "New Paradigms in City Tourism Development" in Barcelona, of Barcelona Turisme, the Barcelona City Council and the Catalan Tourism Board, World Tourism Organization (UNWTO). Retrieved December 15, 2014, from http://blogs.bournemouth.ac.uk/ekotourismlab/research-projects/phd-projects/smart-tourismdestinations-explore-how-smartness-increases-competitiveness-in-the -context-of-tourismdestinations

Cai, Y. (2013). Enhancing context sensitivity of the Triple Helix model: An institutional logics perspective. The Triple Helix XI International Conference, London.

Creswell, J.W. (2002). Educational research: Planning, conducting, and evaluating quantitative and qualitative research. Upper Saddle River, NJ: Merrill/Pearson.

Creswell, J.W. (2007). Qualitative inquiry and research design: Choosing among five traditions. Sage Publications, Thousand Oaks.

Creswell, J.W. (2009). Research design: Qualitative, quantitative, and mixed methods approaches. Sage Publications, Thousand Oaks.

Deakin, M., \& Leudesdorff. (2013). The triple helix model of smart cities: A neo-evolutionary perspective. Imprint Routledge.

Dosi, G., Freeman, C., Nelson, R., Silverberg, G., \& Soete, L. (1988). Technical Change and Economic Theory. London. In J. Sundbo (Ed.), The Theory of Innovation: Entrepreneurs, Technology and Strategy. Cheltenham: Edward Elgar.

Etzkowitz, H., \& Leyedesdorff, L. (2000). The Dynamics of Innovation: From National Systems and 'Mode 2' to a Triple Helix of University-Industry-Government Relations. Research Policy, 29(2), $109-123$.

europeansmart cities. (n.d.). Retrieved January 5, 2016, from http:// www.smart-cities.eu

Go, F., \& Govers, R. (2009). Place Branding. London: Palgrave MacMillan.

Johannesson, J.A., Olsen, B., \& Lumpkin, G.T. (2001). Innovation as newness: What is new, how is new, and new to whom? European Journal of Innovation Management, 4(1), 20-31.

Kotler, P., \& Gertner, R. (2002 April). Country as brand, product and beyond: A place marketing and brand management perspective. Journal of Brand Management, 9(4/5).

Kotler, P., Hamlin, M.A., Rein, I., \& Haider, D.H. (2002). Marketing Asian Places (p.443). John Wiley \& Sons (Asia), Singapore.

Krugman, P. (1994). Competitiveness - A Dangerous Obsession. Foreign Affairs, 73(4).

Lendel, V. (2009). Riadenie vztahov so zákazníkmi v podniku. Dizertačná práca. Žilinská univerzita, Fakulta riadenia a informatiky.

Lusch, R.F., \& Webster, F.E. (2011). A Stakeholder-Unifying, Cocreation Philosophy for Marketing. Journal of Macromarketing, 31(2), 129-134.

Maclean's. (2015). National Reputational Ranking. Retrieved October 10, 2015, from http://www.macleans.ca/education/national-reputational-ranking-2016

Morschett, D., Schramm-Klein, H., \& Zentes, J. (2009). Strategic International Management. Gabler Verlag.

Moutinho, L., Rita, P., \& Cury, B. (1996). Expert Systems in Tourism Marketing. New York: Routledge. Patton, Q. (2002). Qualitative research and evaluation methods. Sage Publications, Thousand Oaks.

Porter, M.E. (1998, November/December). Clusters and New Economies of Competition. Harvard Business Review, pp. 77-90.

Reinisto, S.K. (2003, April). Success Factors of Place Marketing: A Study of Place Marketing Practices in Northern Europe and the United States. Helsinki University of Technology, Institute of 
Strategy and International Business, Doctoral Dissertations. ISSN 1457-6929 ISBN 951-22-66857

Rothwell, R., \& Zelveld, W. (1985). Reindustrialization and Technology. Harlow: Longman.

Ward, S.V. (1998). Selling Places - The marketing and promotion of towns and cities 1850-2000. London: Routledge.

Xiao, H., \& Smith, S. (2006). The making of tourism research: Insights from a social science journal. Annals of Tourism Research, 33(2), 490-507.

Yin, R.K. (2009). Case study research: Design and methods (4th ed.). Newbury Park, Sage Publications. 